\title{
Documents in the Firkovich Collection: Valuable Sources on the History of the Jewish Communities in Europe and the Middle East from the $12^{\text {th }}$ to the $19^{\text {th }}$ century
}

\section{Olga Vasilyeva}

National Library of Russia

\begin{abstract}
The paper ${ }^{1}$ presents a survey of the manuscript collections of Abraham Firkovich, and, in particular, of the handwritten documents it contains in Hebrew, Arabic, WestRussian and other languages. These historical documents belonged to the Karaite (mostly of Lithuania), Rabbanite and Samaritan communities, and reflect their life in Europe and the Middle East from the $12^{\text {th }}$ to the $19^{\text {th }}$ century. These historical sources were included in different library funds and described in several inventory handlists; some archival materials have been presented in printed catalogues, and many items have been published and translated into European languages. In the paper, a brief survey of the documents is given, as well as the history of their acquisition by Firkovich and the history of their cataloguing and research over the past 150 years.
\end{abstract}

\section{Keywords}

Abraham Firkovich, Karaites, documental sources, Troki.

The manuscript collection of Abraham Firkovich (1787-1874), ${ }^{2}$ which is housed in the National Library of Russia in St. Petersburg, numbers 20,395 items, mostly codices and fragments along with a number of documents. This paper will address the following questions: how many documents does the collection contain and how old are they; in what languages and where were

1 The paper was read at the conference "Cultures in Conversation: Asian Languages and Culture”, held by Adam Mickiewicz University (Poznan) on October, 28-30, 2013.

${ }^{2}$ For more on the collections, see the online exhibition "Hebrew manuscripts in the National Library of Russia”: http://expositions.nlr.ru/eng/ex_manus/firkovich/ 
they written; what kind of information do they preserve; where did Firkovich acquire them; in which divisions of his collection are they kept? Who described and studied the documents, and in which books can one find information about these handwritten historical sources?

\section{Documents in the First collection ${ }^{3}$}

\begin{tabular}{|c|c|c|c|c|}
\hline Section & Hebrew & $\begin{array}{l}\text { Russian, } \\
\text { Polish, other } \\
\text { European } \\
\text { languages }\end{array}$ & $\begin{array}{l}\text { Turkic } \\
\text { (Turkish, } \\
\text { Tatar, } \\
\text { Karaite) }\end{array}$ & $\begin{array}{l}\text { Inventories, } \\
\text { catalogues }\end{array}$ \\
\hline $\begin{array}{l}\text { Firk. I } \\
\text { Hebr. doc. I }\end{array}$ & $\begin{array}{l}114 \\
(1187-1843)\end{array}$ & & & $\begin{array}{l}\text { Old inventory, }{ }^{4} \\
\text { Catalogue by } \\
\text { Ravrebe }\end{array}$ \\
\hline $\begin{array}{l}\text { Firk. I } \\
\text { Hebr. doc. II }\end{array}$ & $\begin{array}{l}110 \\
(1400-1804)\end{array}$ & & & $\begin{array}{l}\text { Old inventory, } \\
\text { Catalogue by } \\
\text { Ravrebe }\end{array}$ \\
\hline $\begin{array}{l}\text { Firk. I } \\
\text { Hebr. doc.III }\end{array}$ & $\begin{array}{l}33 \\
(1149-1811)\end{array}$ & & & $\begin{array}{l}\text { Old inventory, } \\
\text { catalogue by } \\
\text { Ravrebe }\end{array}$ \\
\hline $\begin{array}{l}\text { Firk. I } \\
\text { Pol. doc. }\end{array}$ & & $\begin{array}{l}334 \\
(1507-1848)\end{array}$ & & $\begin{array}{l}\text { Inventory by } \\
\text { A. Romanova }\end{array}$ \\
\hline $\begin{array}{l}\text { West-Russian } \\
\text { deeds }^{5} \text { (partly) }\end{array}$ & & $\begin{array}{l}120 \\
(1493-1694)\end{array}$ & & New inventory \\
\hline $\begin{array}{l}\text { Firk. I. } \\
\text { Turk. doc. }\end{array}$ & & & $\begin{array}{l}65 \\
(1698-1840)\end{array}$ & New inventory \\
\hline total & $\mathbf{2 5 7}$ & 454 & 65 & 766 \\
\hline
\end{tabular}

In 1862 Alexander II bought for the Imperial Public Library a collection which later received the name "the First Firkovich collection". It was accompanied

3 The First Firkovich collection is divided into the following sections: Hebr. I; Biblical mss; Odessa collection A, B, C; Hebr. doc. I, II, III; Pol. doc.; Turk. doc.

4 The handwritten catalogue in German was supposedly firstly prepared by Abraham Firkovich himself and translated into German by an unknown person ca. 1862 (Firk. arch. N. 1068).

5 The collection (Zapadno-russkie akty) is kept in the Russian archive sector of the Manuscript Department of the National Library of Russia.

${ }^{6}$ New inventory (here and further) - typed list of the collection prepared by librarians on the basis of old catalogues and other descriptive documentation, and stocktaking. 
with a handwritten catalogue in the German language (Fig. 1) in which the manuscripts were divided into several large parts. The documents in Hebrew were described in the first part of the catalogue as three groups.

The first group consists of 114 documents. They include correspondence between Karaite communities; between Rabbanite and Karaite communities; and personal correspondence between Karaites, as well as marriage contracts, etc. If Firkovich could not acquire an original document he made a copy. Thus, he copied a letter written by Solomon ben Abraham from Kafa to Inkerman dated 1381 (Fig. 2). One of the earliest original documents in the first group is the decision of the Karaite community of Damascus prohibiting the bringing of complaints to non-Karaite courts, written in 1500 in Hebrew and Arabic (Fig. 3). The oldest one is a damaged fragment of an appeal to Jewish communities to help poor men, dated 1149 (Firk. I. Doc. I. N. 119).

110 documents $^{7}$ of the Lithuanian ("Polish") Karaite community are included in the second group. The earliest letters date to the 1480s: this is correspondence between the Karaites of Troki, Lutsk and Constantinople about the "dissolution of morals" among the Lithuanian Karaites, and a polemic between Ilyah Bashyachi and Moses of Kiev (Firk. I. Doc. II, N. 37-46).

Rabbanite marriage contracts and other documents, 33 in all, are gathered in the third group of documents in the catalogue.

Adolf Neubauer was the first scholar to take notice of this material. He published or mentioned six documents from the first group and eighteen documents from the "Polish" group. ${ }^{8}$ Among these is a letter of condolence (with 15 signatures) from Lutsk, written in 1796 to the Karaite shofet Samuil ben Abraham after a fire in Troki in which the kenese was burned down (Fig. 4). The letter also informs that Catharine the Great exempted the Crimean Karaites from an extra tax of 15 zlotys from each male, and the question is posed how the same kind of relief could be obtained by the Polish and Lithuanian Karaites.

This letter was also published in 1945 by Jacob Mann ${ }^{9}$ in the second volume, entitled Karaitica, of his Texts and Studies in Jewish History and Literature.

7 In the Catalogue 125 items/numbers are described, although not all of them entered the Library.

8 Neubauer 1866:139-145.

9 During his stay in Leningrad, Mann was assisted by David Maggid (1862-1942), who worked at the Library as the head of the printed Judaica Department from 1918 to 1930. 
All in all, he published 98 documents from the "Polish" part, or $78 \%$ of their total number.

The names of Neubauer and Mann and their contributions to Jewish and, in particular, Karaitic studies are well known. I would like to draw attention, however, to a researcher whose name is unknown because he had no chance to publish his works, although his role in the description of the Firkovich collection was crucial.

Iehiel Ravrebe (1883-1938), son of a melamed from the Volin province, worked at the Manuscript Department of the State Public Library from 1931 to 1937 , when he was arrested, and died soon afterwards. ${ }^{10}$ Over a period of six years he was able to describe approximately 6,000 Hebrew manuscripts from the collections of both Archimandrite Antonin (about 1,00o fragments from the geniza of Ibn Ezra synagogue in Old Cairo) and Abraham Firkovich. In addition to several inventory hand-lists and card catalogues, Ravrebe composed the descriptive catalogue of the Hebrew documents in the First Firkovich collection, ${ }^{11}$ two type-written copies of which are preserved (Fig. 5).

The catalogue includes a full description of 252 documents, which are divided by author into the following ten categories:

1. Community affairs, congresses, courts, migrations and benevolence (1-56)

2. Inheritance law (57-74)

3. Marriage contracts and divorce documents (75-115)

4. Bills of sale and exchange (116-122)

5. Letters and material from historical sources (123-148)

6. Commerce and money matters (149-151)

7. Welcoming letters, poems, elegies, necrologies, grave inscriptions (152-172)

8. Varia $(173-179)$

9. Religious questions. Karaites and Rabbinates. Calendar numeration (180-212)

10. Lithuanian Vaad and the Karaites. State and community taxes and duties (213-252).

${ }^{10}$ See: Шилов (гл. ред.) 2003: 464-465.

${ }^{11}$ Ravrebe could not have used the descriptions of Jacob Mann, as, first, he did not work at the Library at the time of Mann's visit; and second, the Mann's book appeared after Ravrebe's death. 
This "list of contents" explains very well the types of documents and their subjects. Many items, originating from the Middle East, were collected by Firkovich during his first trip to Palestine in 1830 and during his two-year stay in Istanbul as a teacher. The provenance of another part of the collection is also clear - it originated from the Crimean communities of Karaites and Rabbanite-Krimchaks. However, about half of the documents clearly belonged to the Lithuanian communities, chiefly that in Troki (Fig. 6). Of these, three marriage contracts have been discussed by Tapani Harviainen. ${ }^{12}$

In 1853 Firkovich left Eupatoria for Vilna, and stayed in Lithuania during the Crimean war till 1856. He managed to take from the Karaite authorities not only the documents in Hebrew, but in other languages as well, mostly in socalled West-Russian (or Ruthenian), the official literary language of the Grand Duchy of Lithuania. This part of the collection is described by Anastasiya Romanova and Boris Zaykovsky in a joint article published both in Russian and in English. ${ }^{13}$ Here I will just briefly repeat the main data contained within it.

In the 188 os when S. A. Bershadsky was working on his books on Lithuanian Jews, ${ }^{14}$ he most likely described a number of documents in West-Russian from the Firkovich collection. Later, in 1920, they (about 120 items) were combined with other charters from other collections in this language to form the library fund called "West-Russian deeds", which numbers in all 477 items. The rest of the West-Russian documents from the Firkovich collection, as well as ones in Polish and Latin, and even Russian translations of documents, were not described until the 1990s, when Anastasiya Romanova made a hand list of the fund named "Polish documents". It now includes 334 items: original juridical documents, copies and translations, from the late $14^{\text {th }}$ to the $19^{\text {th }}$ century.

All the documents concern the rights and position of the Karaites, primarily those in Troki. Among them are charters of the Lithuanian prince Alexander (1493, 1505) and the Polish kings Sigismund I (Fig. 7), Henry Valois and Stefan Batory. Other papers include documents from voivodes (governors) and the Catholic authorities (Fig. 8); receipts of taxes and other financial papers;

\footnotetext{
${ }^{12}$ Harviainen 2007.

13 ЗАЙКОвСКИЙ, Романова 2003; Romanova, ZaikovsKi 2003.

${ }^{14}$ БЕРШАДСКИЙ 1882; БЕРШАДСКИЙ 1883.
} 
court decisions and private documents. Four items were published in Bershadsky's last book. ${ }^{15}$

These West-Russian and Polish documents, as well as a part of the Hebrew ones, comprise the archive of the Karaite community of Troki. It is known that in 1853 (before Firkovich reached Troki), the Lithuanian Karaites forwarded a petition to Nicolas I in which they asked for the restoration of their rights and privileges. To the petition they added documents which a year earlier had been assembled and translated into Russian. Some originals were sent to the civil governor of Vilna A.O. Rosset in 1855. It is also known that Firkovich was considered the solicitor of the Karaites in the Russian capital, ${ }^{16}$ so the archive could have been given to him in exchange for his help and/or as historical support for his efforts.

In addition to the above-mentioned documents, the First Firkovich collection also includes 85 items in Turkic languages (Turkish, Tatar and Karaite) concerning the Karaites' lives in the Crimean Khanate from the $17^{\text {th }}$ through the end of the $18^{\text {th }}$ century. In the list, according to which the collection was acquired, they are characterized very briefly: "Different documents in the Turkish language, including 6 copies - total 53", and "Accounts of Khan-Saray (khans' palace) and mint place $-12 "{ }^{17}$

Many of the Turkish documents were described by St. Petersburg University professor Vasiliy D. Smirnov, who worked in the Library for some 40 years. He also translated into Russian eight yarliks (charters/diplomas) of the Crimean khans from Salamat-Giray (1706) to Shahin-Giray (1778). His translations and the texts of six yarliks were included in the "Collection of old charters and statutes of the Russian Empire concerning the rights and states of the Russian-subject Karaites", ${ }^{18}$ which was published in 1890 under the sponsorship of Zarya Abramovich Firkovich, the son of Abraham Firkovich. In the preface to this book, Smirnov wrote particularly: "Out of these yarliks, we see that the community of the Chufut-Kale inhabitants - "Yahudi" was

\footnotetext{
15 БЕРшАДСКий 1903.

${ }^{16}$ Vinnovich 2012: 151-152.

17 "Разных документов на турецком языке, в том числе 6 копий - 53"; “Счеты ХанСарая и монетного двора - 12" (National Library of Russia. F. 946, op. 1. Firkovich Archive. N. 138, f.107; see also N. 1057).

18 Фиркович (изд.) 1890: 57-105.
} 
recognized by the khan's authority as a political unity, which was granted various legal privileges and guarantees of internal living independence." ${ }^{19}$

Smirnov also published the text of three other yarliks in his reading book "Exemplary works of Turkish literature", ${ }^{20}$ facsimile copies of which were made by murza I. A. Boragansky, who was trained as a calligrapher in Istanbul. Among the published documents is a yarlik of Muhammad Giray (16541656), giving the right to Mordehay to sell three slaves (Fig. 9).

\section{Documents in the Second Collection ${ }^{21}$}

\begin{tabular}{|c|c|c|c|c|c|}
\hline Section & Hebrew & $\begin{array}{l}\text { Russian, } \\
\text { European } \\
\text { languages }\end{array}$ & Arabic & $\begin{array}{l}\text { Hebrew, } \\
\text { Samaritan } \\
\text { script }\end{array}$ & Inventories, catalogues \\
\hline $\begin{array}{l}\text { Samaritan } \\
\text { mss. X. } \\
\text { Sam. doc. }\end{array}$ & & & & $\begin{array}{l}94 \\
(1510-1864)\end{array}$ & $\begin{array}{l}\text { New inventory, } \\
\text { ВильскЕР 1992, } \\
\text { PuмMER 1993-1997 } \\
\end{array}$ \\
\hline $\begin{array}{l}\text { Samaritan } \\
\text { mss. XIV. } \\
\text { Arab. doc. }\end{array}$ & & & $\begin{array}{l}45 \\
(1469-1845)\end{array}$ & & $\begin{array}{l}\text { New inventory, } \\
\text { ЛЕБЕДЕв } 1978\end{array}$ \\
\hline $\begin{array}{l}\text { Firk. II. } \\
\text { Arab. doc. }\end{array}$ & & & $\begin{array}{l}174 \\
(1158-1814)\end{array}$ & & $\begin{array}{l}\text { New inventory, } \\
\text { ЛЕБедЕв } 1978\end{array}$ \\
\hline $\begin{array}{l}\text { Firk. II K. } \\
\text { (marriage } \\
\text { contracts) }\end{array}$ & $\begin{array}{l}76 \\
(1367-1851)\end{array}$ & & & & New inventory \\
\hline $\begin{array}{l}\text { Firk. II } \\
\text { Hebr. II. } \\
\text { A (partly) }\end{array}$ & about 200 & & & & New inventory \\
\hline $\begin{array}{l}\text { Firkovich } \\
\text { archive } \\
\text { (partly) }\end{array}$ & about 500 & about 300 & & & New inventory \\
\hline Total & about 800 & about 300 & 219 & 94 & about 1400 \\
\hline
\end{tabular}

19 Фиркович (изд.) 1890: XVII.

${ }^{20}$ Смирнов 1891: 474; see also Смирнов 1887: 575.

${ }^{21}$ The Second Firkovich collection includes Samaritan mss, I-XIV, and the Firkovich personal archive as separate divisions, while other materials are divided into following sections: Hebr. II A; Hebr. II B; Hebr. II. C; Judeo-Arab. I; Judeo-Arab. II; Arab.-Hebr.; Arab.; Arab. doc, Hebr. II. K (ketubbot). 
We have to conclude that before 1864, the year of his second trip to the Middle East, Firkovich became quite convinced of the present and future importance of these old historical sources. This is why during his journey to the cities of Palestine, Syria and Egypt Firkovich gathered a huge collection of manuscripts, including these documents.

First, he acquired the geniza of the Samaritan community of Nablus. ${ }^{22}$ In 1870 he sold to the Public Library the Samaritan collection of about one thousand items, including 94 marriage contracts (in Hebrew language but in Samaritan script) beginning from 1510 . They were described in the catalogues of Leib H. Vilsker ${ }^{23}$ and Reinhard Pummer, ${ }^{24}$ who also published the texts and the images. In the Samaritan collection 45 letters in Arabic from 1469 till 1845 are also kept. Their descriptions are included in the Catalogue of the Arabic documents. ${ }^{25}$

In Cairo, Firkovich bought the geniza of the Karaite synagogue (kenese). Among the numerous damaged parchment and paper sheets not only fragments of codices but also documents were found. ${ }^{26}$ This acquisition is the bulk of the Second Firkovich collection which was bought by the Government for the Library in 1876. Firkovich himself divided the collection into several divisions, although he did not finish this work and did not compose any inventory list. Over several decades, librarians, most of all Abraham Harkavy and Yehiel Ravrebe, worked on the description of the collection. As a result, 13 divisions were formed based on different principles, such as the language and content of the manuscripts. Two divisions include only documents, namely, "Arabic documents" and "Marriage contracts". The first contains 174 items beginning from the $12^{\text {th }}$ century, the descriptions of which were published in the abovementioned catalogue by Lebedev. As for the Karaite marriage contracts (in Hebrew), there were 76 items dated between 1367 and $1851 .{ }^{27}$

\footnotetext{
${ }^{22}$ See in details: Harviainen, ShehadeH 1994.

${ }^{23}$ Вильскер 1992. Semitologist Leib Vilsker (1919-1988) worked in the National Library of Russia from 1950 to 1979 as a curator of printed Judaica collection. He published more than 100 works, among them articles on Samaritan and Hebrew manuscripts.

${ }^{24}$ Pummer 1993-1997.

25 ЛЕБЕДЕв 1978.

${ }^{26}$ See details in: HARVIAINEN 1996.

${ }^{27}$ All of them are included in the on-line exhibition: http://expositions.nlr.ru/ex_manus/ firkovich_ketubah/
} 
In addition, some documents in Hebrew were included in the division "Hebrew II A", which contains about 4,000 codices and fragments of narrative works. Jacob Mann published 78 documents (letters) from this division.

During the decades of cataloguing, other divisions were compiled, among them the Firkovich archive, which consists of 1,000 items in Hebrew, Russian and other languages. Some of them are drafts of his work (including descriptions of the manuscripts in his collection) or works by other persons; there are also letters written to or by Firkovich, as well as other documental materials. Among the scholars who have based their research on the Firkovich archive are Tapani Harviainen ${ }^{28}$, Golda Akhiezer, Dan Shapira, Mikhail Kizilov, Zeev Elkin and Menahem Ben-Sasson ${ }^{29}$.

To sum up, the First Firkovich collection includes 776 documents in original and copies, of which 257 are written in Hebrew, 65 in Turkic languages (in Arabic script) and 454 documents in European languages (West-Russian, Russian, Polish, Latin). Most of them originate from Lithuania, as well as from the Crimea, and represent the life of the Karaite and Rabbanite communities beginning in the $12^{\text {th }}$ century.

As for the Second Firkovich collection, we know the exact numbers of Arabic documents: 174 from Cairo and 45 from Nablus, from which 94 Samaritan documents in Hebrew also originate. The number of Hebrew documents is still uncertain (with the exception of 76 marriage contracts), as they were included in the huge division "Hebr. II A". From both of them, Jacob Mann published 113 items. However, one can discover more documental materials, especially among the newly described portion of the above-mentioned "Hebr. II A" division. The Firkovich archive is also to be examined in order to decide which material may be considered documental and which not.

At the moment we can state that more than 2,000 items or $10 \%$ of the entire Firkovich collection consists of documental sources, mostly on Karaite history.

\footnotetext{
${ }^{28}$ Harviainen 1999.

${ }^{29}$ ElKin, Ben-SASSON 2002.
} 


\section{References}

Elkin Zeev, Ben-Sasson Menahem. 2002. Abraham Firkovich and the Cairo genizas in the light of his personal archive. Pe'amim: Studies in Oriental Jewry. 90, Winter. Jerusalem. Ben-Zvi Institute, 51-95.

Harviainen Tapani, Shehadeh Hasseb. 1994. How did Abraham Firkovich acquire the great collection of Samaritan manuscripts in Nablus in 1864? Studia Orientalia. Vol. 73. Helsinki. Finnish Oriental society, 167-187.

Harviainen Tapani. 1996. The Cairo genizot and other sources of the Second Firkovich collection in St. Petersburg. Proceedings of the Twelfth Congress of the International Organization for Masoretic Studies 1995, Masoretic Studies. 8. Ed. by E.J. Revell. The Society of Biblical Literature, Scholars Press, 25-36.

HaRviaInEN Tapani. 1999. Abraham Firkovich as collector of dispersed minorities and their manuscripts in the light of his archive in St. Petersburg. Jewish Studies. Journal of the World Union of Jewish Studies, Vol. 39, Jerusalem, 97-106.

HARVIAINEN Tapani. 2007. Marriage contracts and items of dowry among the Karaims in Eastern Europe. Studia Orientalia. Vol. 101. Helsinki. Finnish Oriental society, 61-83, plates $1-4$.

Neubauer Adolf. 1866. Aus der Petersburger Bibliothek: Beiträge und Documente zur Geschichte des Karäerthums und der karäeischen Literatur. Leipzig.

ManN Jacob. 1945. Texts and studies in Jewish history and literature. Vol. 2. Karaitica. Philadelphia.

Pummer Reinhard. 1993-1997. Samaritan marriage contracts and deeds of divorce. Vol. 1-2. Wiesbaden: Otto Harrassovitz.

Romanova Anastasiya A., Zaikovski Boris I. 2003. Polish documents in the A. S. Firkovich collection. Studia Orientalia. Vol. 95. Helsinki. Finnish Oriental society, 79-92.

БЕРшАдский Сергей А. 1883. Литовские евреи, история их юридического и общественного положения в Литве от Витавта до Люблинской унии: 1388-1569. Санкт-Петербург.

БЕршАдский Сергей А. 1882. Русско-еврейский архив. T. 1-2. Документы и регесты к истории литовских евреев: Из актовых книг Метрики Литовской, Виленского центрального архива и некоторых печатных изданий. Санкт-Петербург. 
БЕршадский Сергей А. 1903. Русско-еврейский архив. Т.3. Документы и материалы для истории евреев в России: Документы к истории польских и литовских евреев (1364-1569). Санкт-Петербург.

Вильскер Лейб Х. 1992. Самаритянские документы Государственной Публичной библиотеки имени М. Е. Салтыкова-Щедрина: Каталог. СанктПетербург.

Вихнович Всеволод Л. 2012. Караим Авраам Фиркович: Еврейские рукописи. История. Путешествия. Санкт-Петербург.

ЗАйковский Борис И., РомановА Анастасия А. 2003. «Польские документы» собрания А. С. Фирковича. Восточный сборник. Выпуск 6. Санкт-Петербург, Российская национальная библиотека, 36-50.

ЛЕБедев Виктор В. 1978. Арабские документы IX-XX вв. Каталог. Ленинград, Публичная Библиотека им. М. Е. Салтыкова-Щедрина.

Смирнов Василий Д. 1887. Крьмское ханство до начала XVIII столетия. Санкт-Петербург.

Смирнов Василий Д. 1891. Образцовые произведения османской литературы в извлечениях и отрывках. Санкт-Петербург.

Шилов Леонид А. (гл. ред). 2003.Сотрудники Российской национальной библиотеки - деятели науки и культуры: Биографический словарь. Т. 3. Государственная Публичная библиотека в Ленинграде - Государственная Публичная библиотека имени М. Е. Салтыкова-Щедрина: 19311945. Санкт-Петербург.

Фиркович Заря А. (изд.). 1890. Сборник узаконений Российской империи касательно русско-подданных караимов. Санкт-Петербург.

Olga Vasilyeva is head of the Section of Oriental collections in the Manuscript Department of the National Library of Russia. Her fields of interest include Turkish literature, the history of Oriental manuscript collections, the art of the book, and the codicology of Oriental manuscripts. She is the author of some 100 published works, including the album Hebrew Manuscript Ornament (Moscow-Tel Aviv, 2003, compiled in collaboration with Boris Zaikovsky and Alexander Kantsedikas) and the album A String of Pearls: Iranian Fine Books from the $14^{\text {th }}$ to the $17^{\text {th }}$ Century in National Library of Russia Collections (St-Petersburg, 2009), as well as articles on the Firkovich collection. 


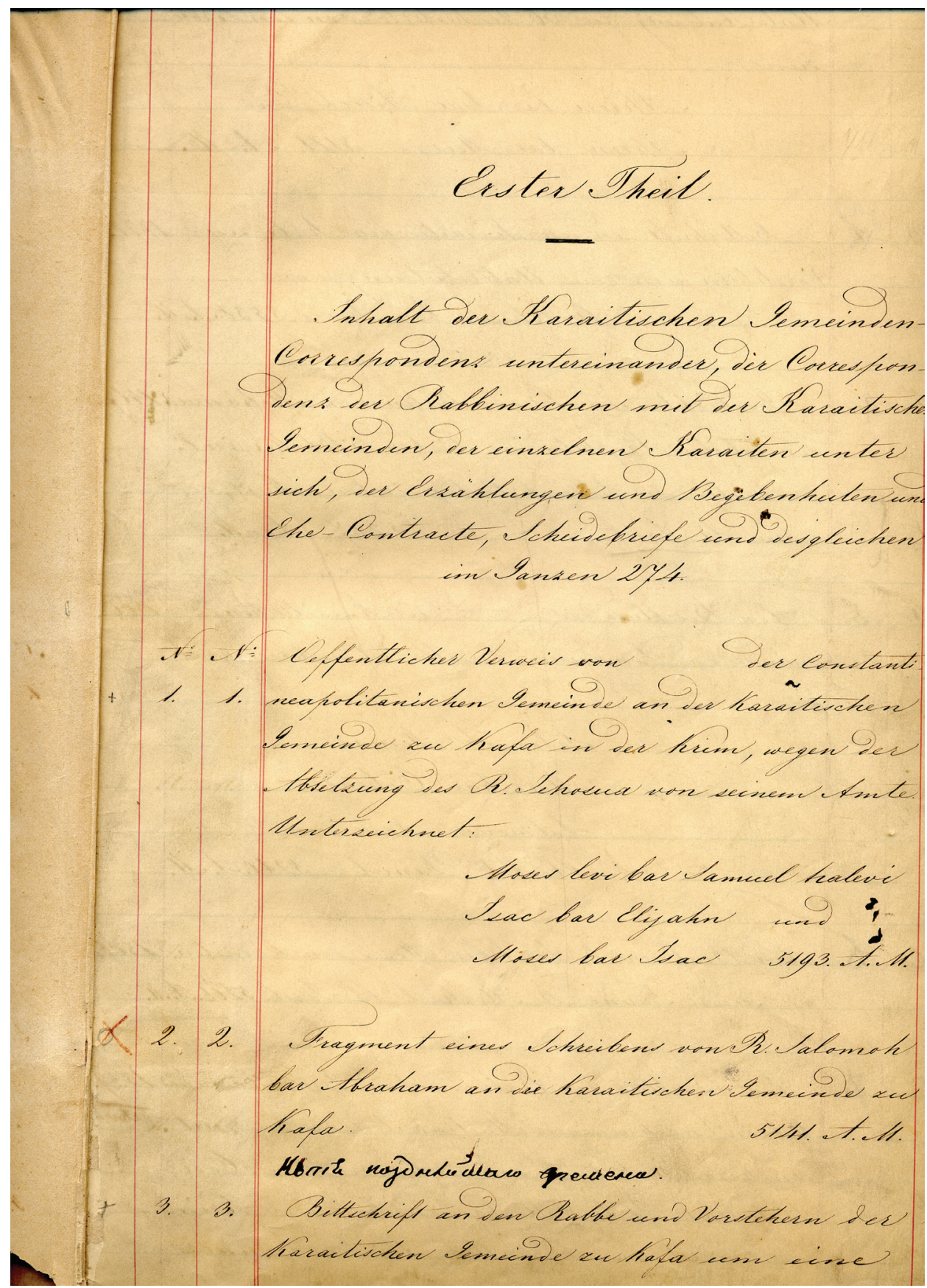

Old catalogue of the First Firkovich collection. Ca. 1864. National Library of Russia. Firk. arch., N. 1068, f. 1. 


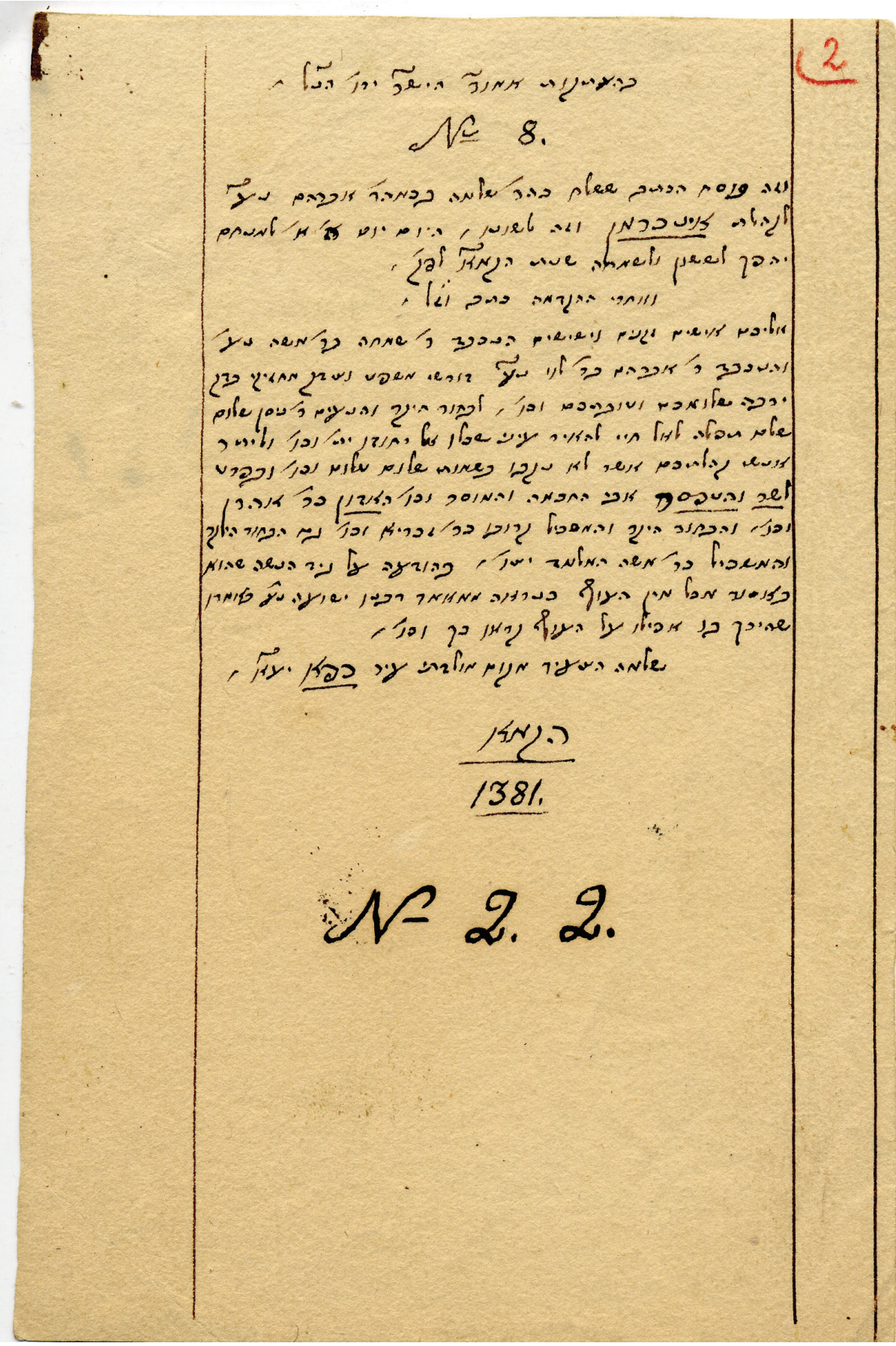

Letter of Solomon ben Abraham from Kafa to Inkerman. 1381 (date of original). Copied by Abraham Firkovich in 1830 -1850s. National Library of Russia. Firk. I Hebr. doc. I, N. 1. 


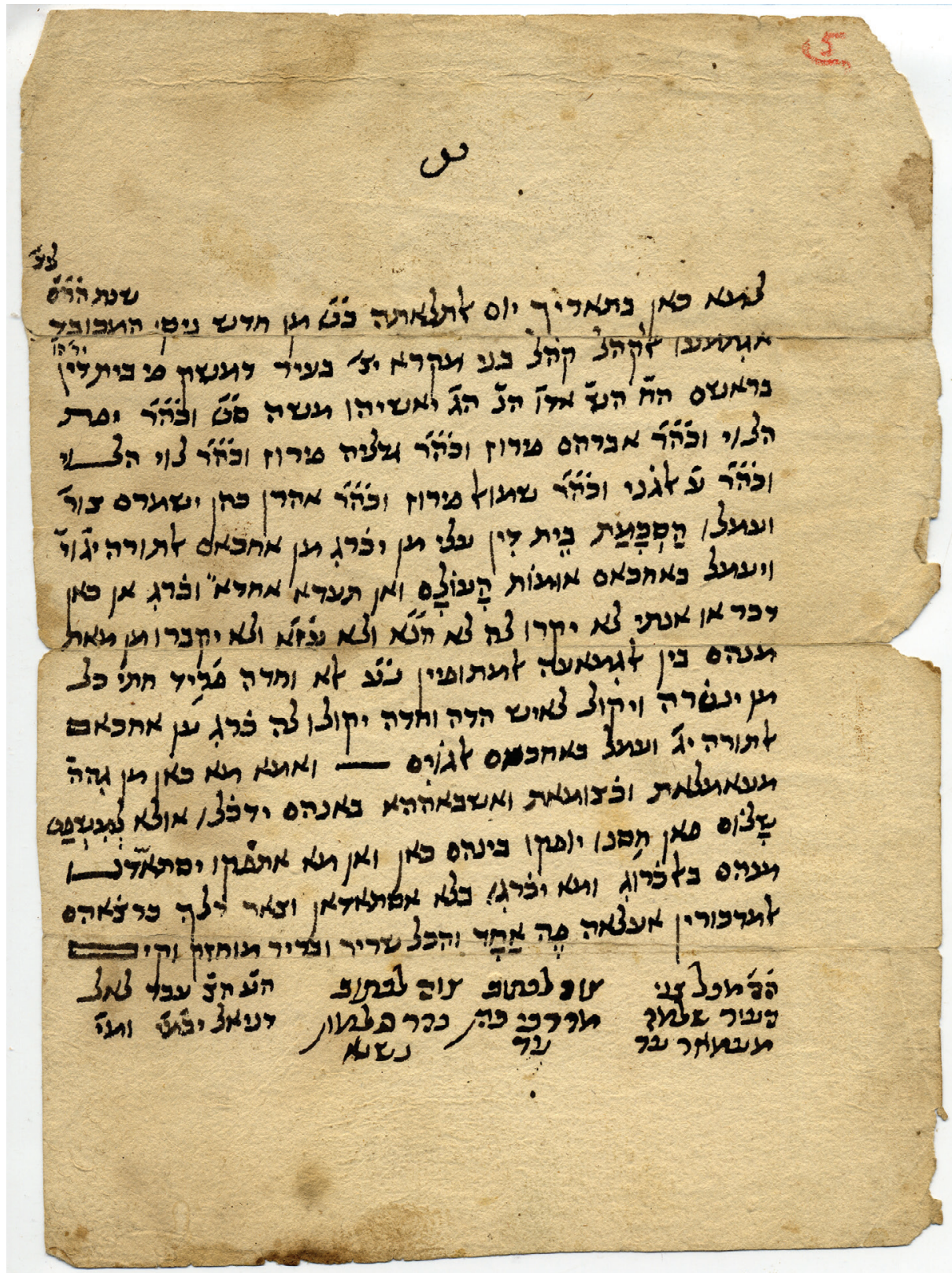

Decision of the Karaite community of Damascus, prohibiting the bringing of complaints to non-Karaite courts. Hebrew and Arabic. 1500. National Library of Russia. Firk. I Hebr. doc. I, N. 5. 


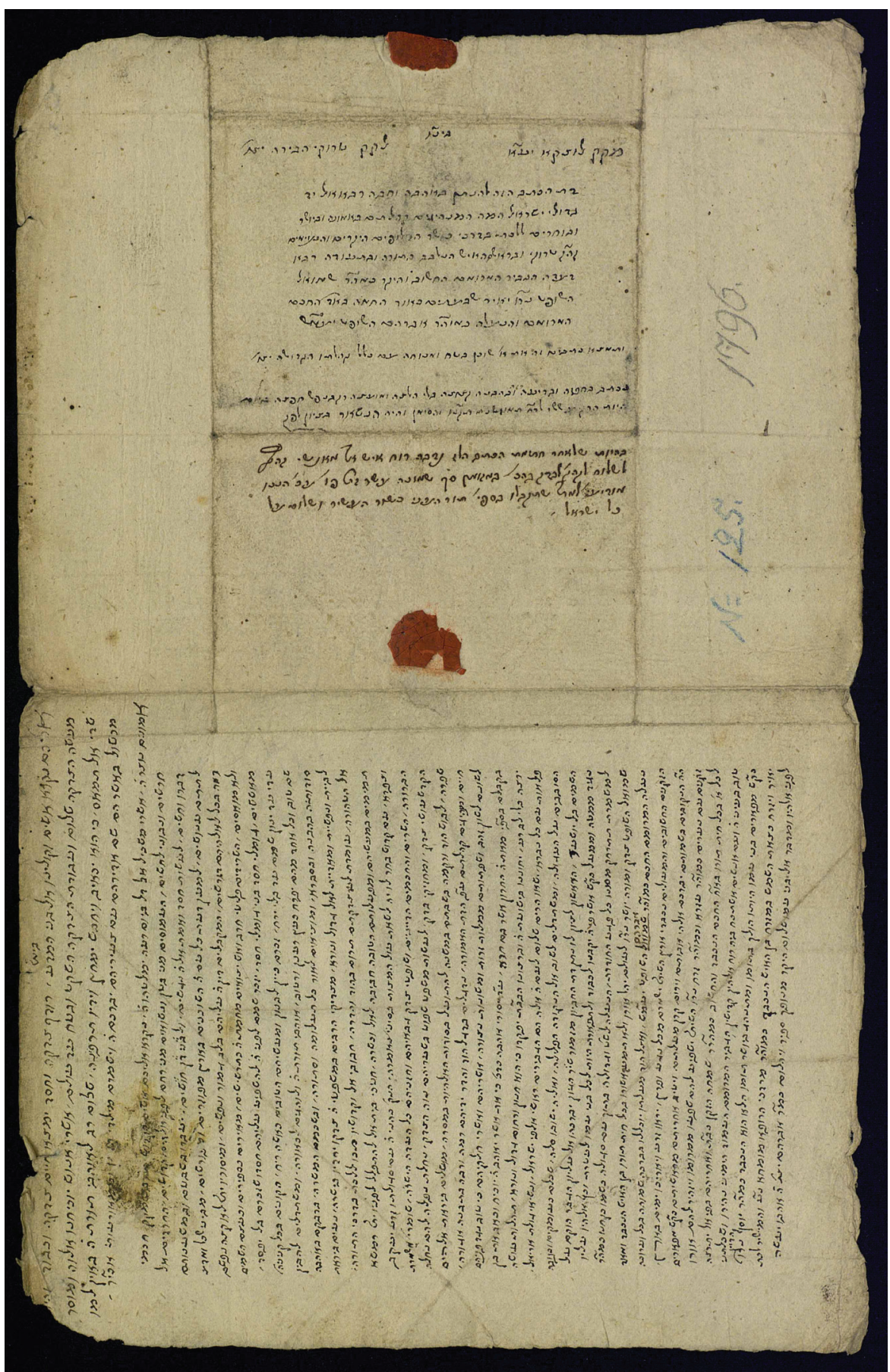

Letter of condolence from Lutsk to the Karaite shofet Samuil ben Abraham. 1796. National Library of Russia. Firk. I Hebr. doc. II, N. 125. 


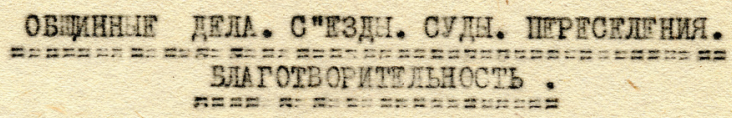

II 49.

Воззвание $\mathrm{k}$ өврейскии обнинан $\mathrm{C}$ пркзивон понегать боднии и участвовать в бла готворительнит делах.

Начало й конец такста крей нө повревдены. Лищь с трудои можно прочи тать в первой эгроке: /1149r.|, a B прздпоследнег строшке сиизу :

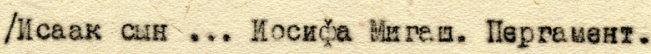

I л. $98 \times 16$ сu., почерк полукведра тний .

/HrB. III I $/$.

I $42 I$ r. $/$ /

Обрадөие $\mathrm{k}$ Хахану и пред ставителяи караинской обнини

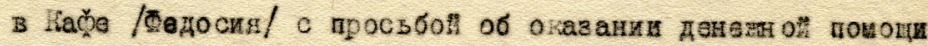
эридцати раббанитаи, огправизииися в Палестину, но в дороге потерпевич кораблекрушение и велавия варнуться в ПольMy.

Пата 5181 / /.Подписано

I $0 . .16,3$ xII cu. nочерк курсиз / Mив.I. $3 /$.

I42I г. / /

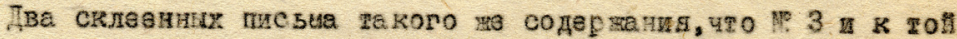
zа обциня. Оба пись ча подиисана

Тата не указане.

2 л. IIxI6 cu., почарк курскв /Paши/.

Инв. $1.3 \mathrm{a} /$.

Iehiel Ravrebe. Catalogue of the documents in the First Firkovich collection. 1935-1938. National Library of Russia. Firk. arch., N. 1064, f. 2. 


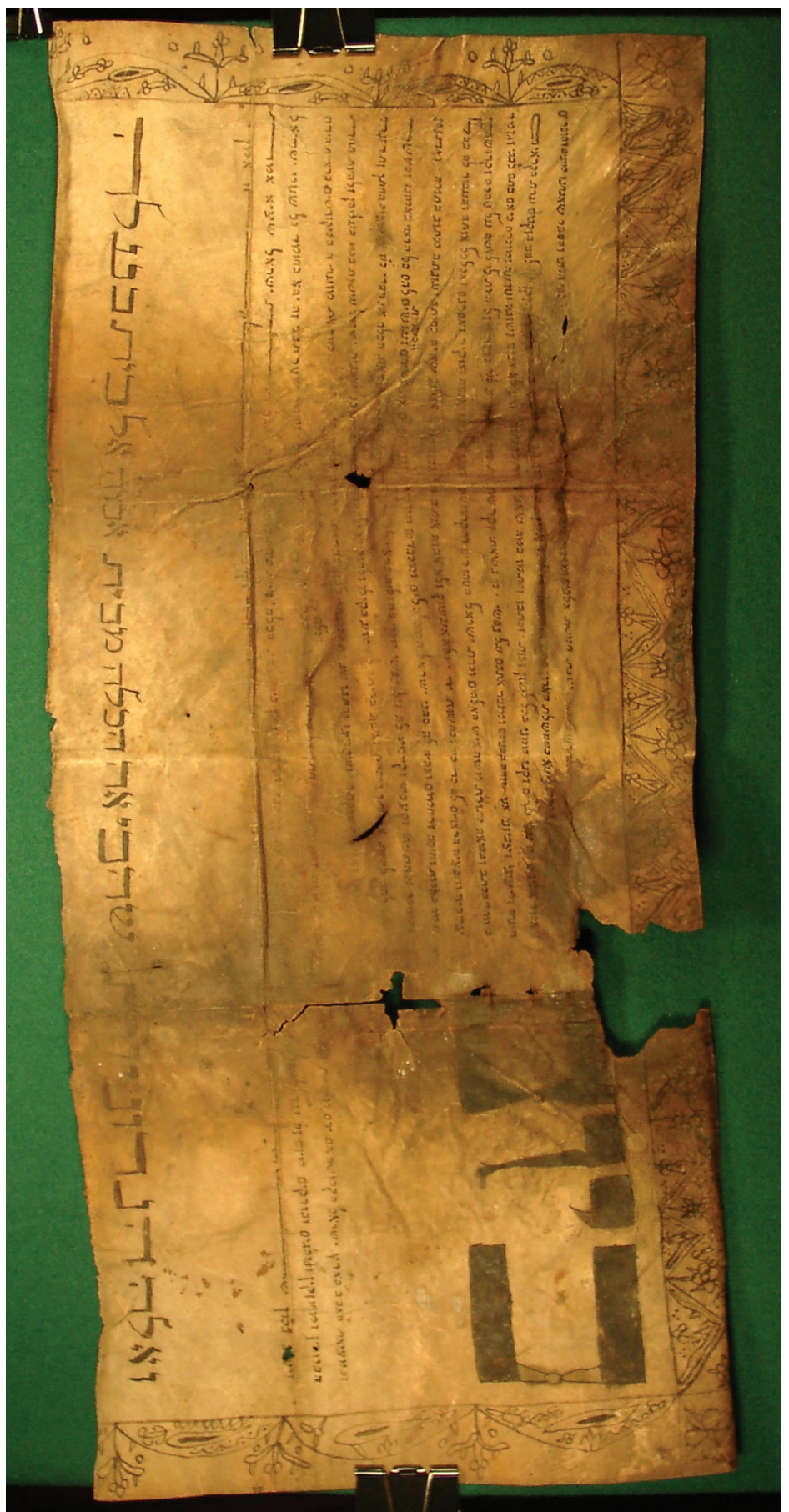

Fragment of the ketubba of 1400. National Library of Russia. Firk. I Hebr. doc. II, N. 1. 


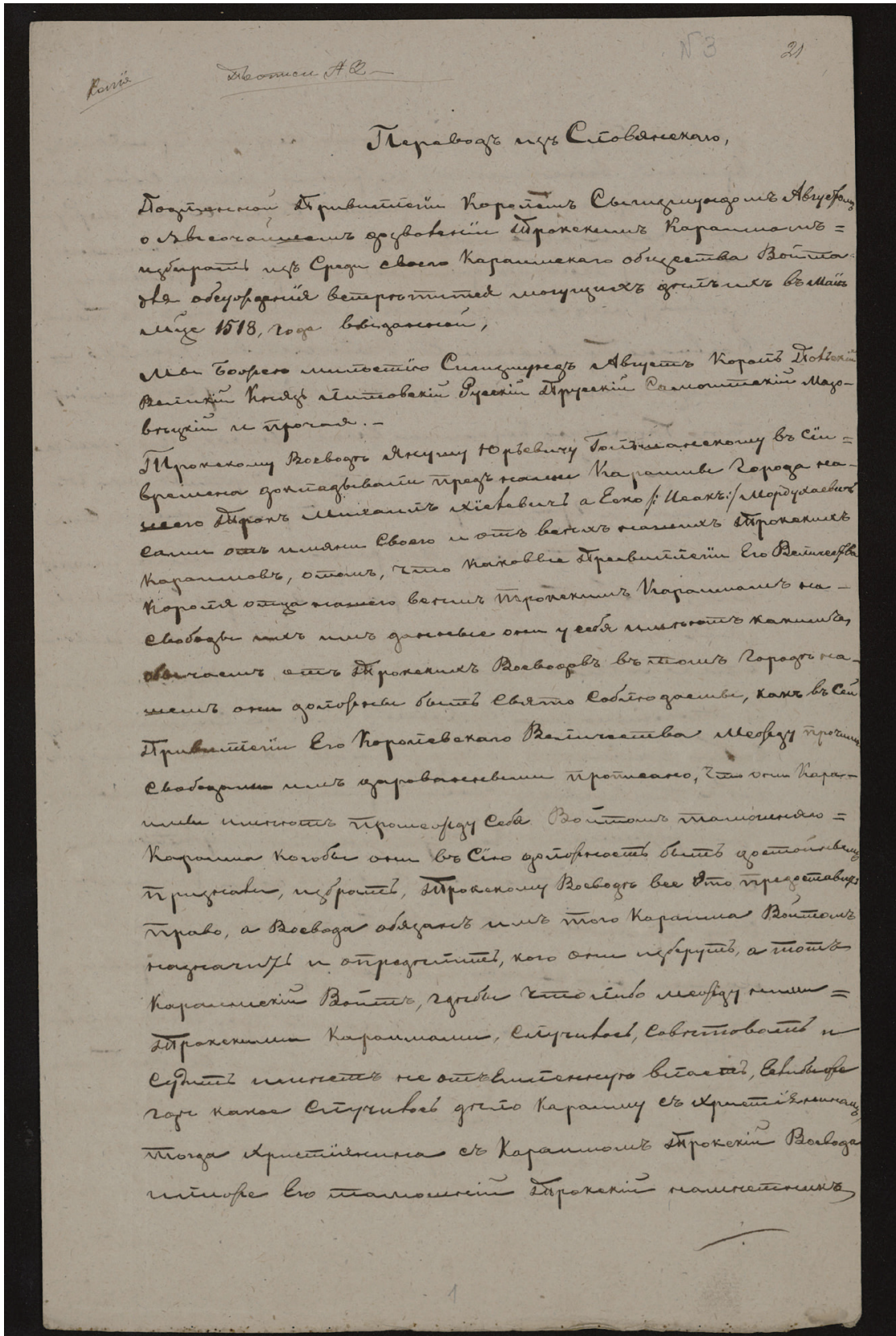

Charter of the Polish king Sigismund I concerning the rights of the Karaites of Troki. 1507 (date of original), copy of the $18^{\text {th }}$ century. National Library of Russia. Firk. I. Pol. doc., N. 3. 


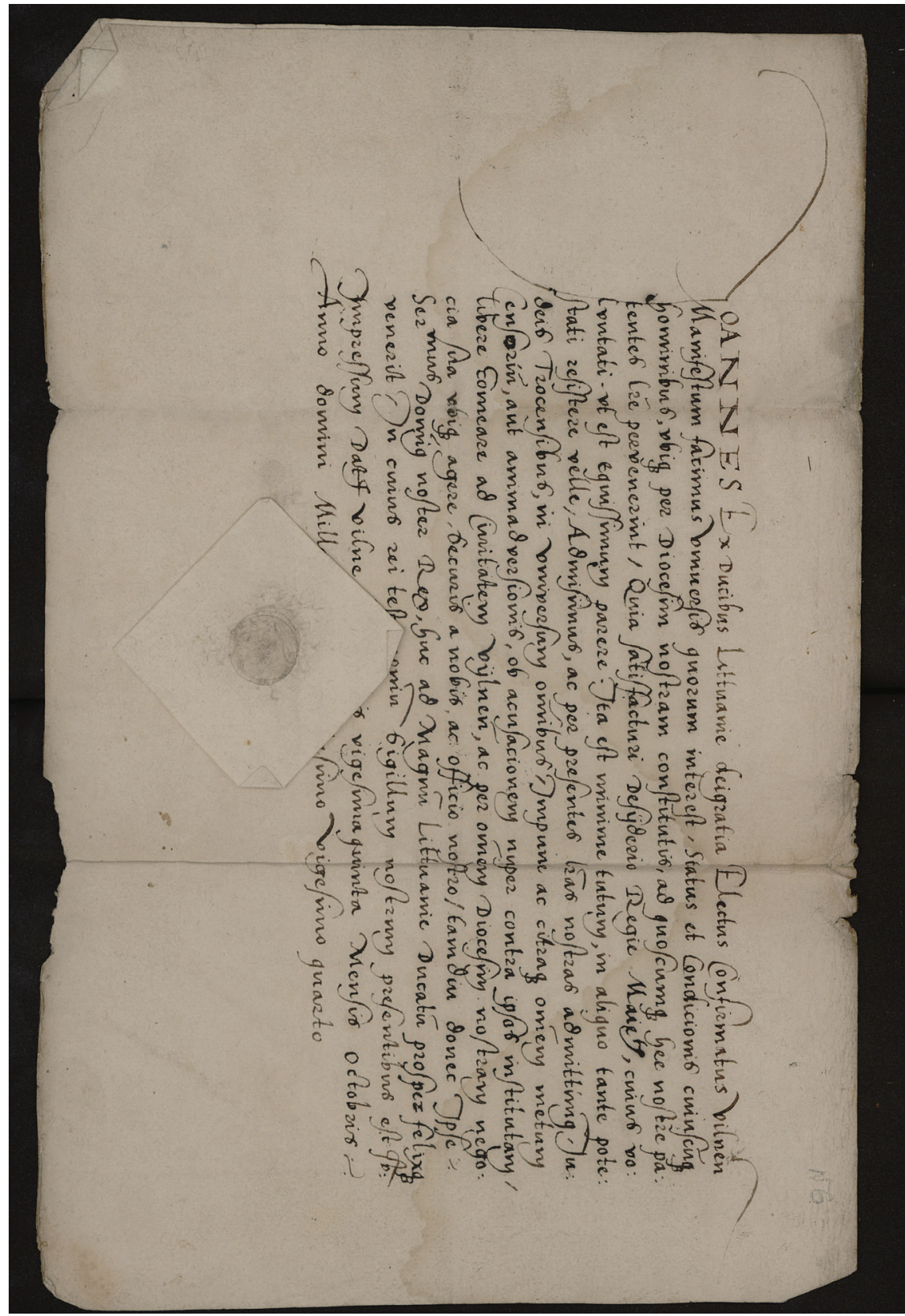

Charter of Ioann, the Bishop of Vilna. 1524. National Library of Russia. Firk. I. Pol. doc., N. 6. 


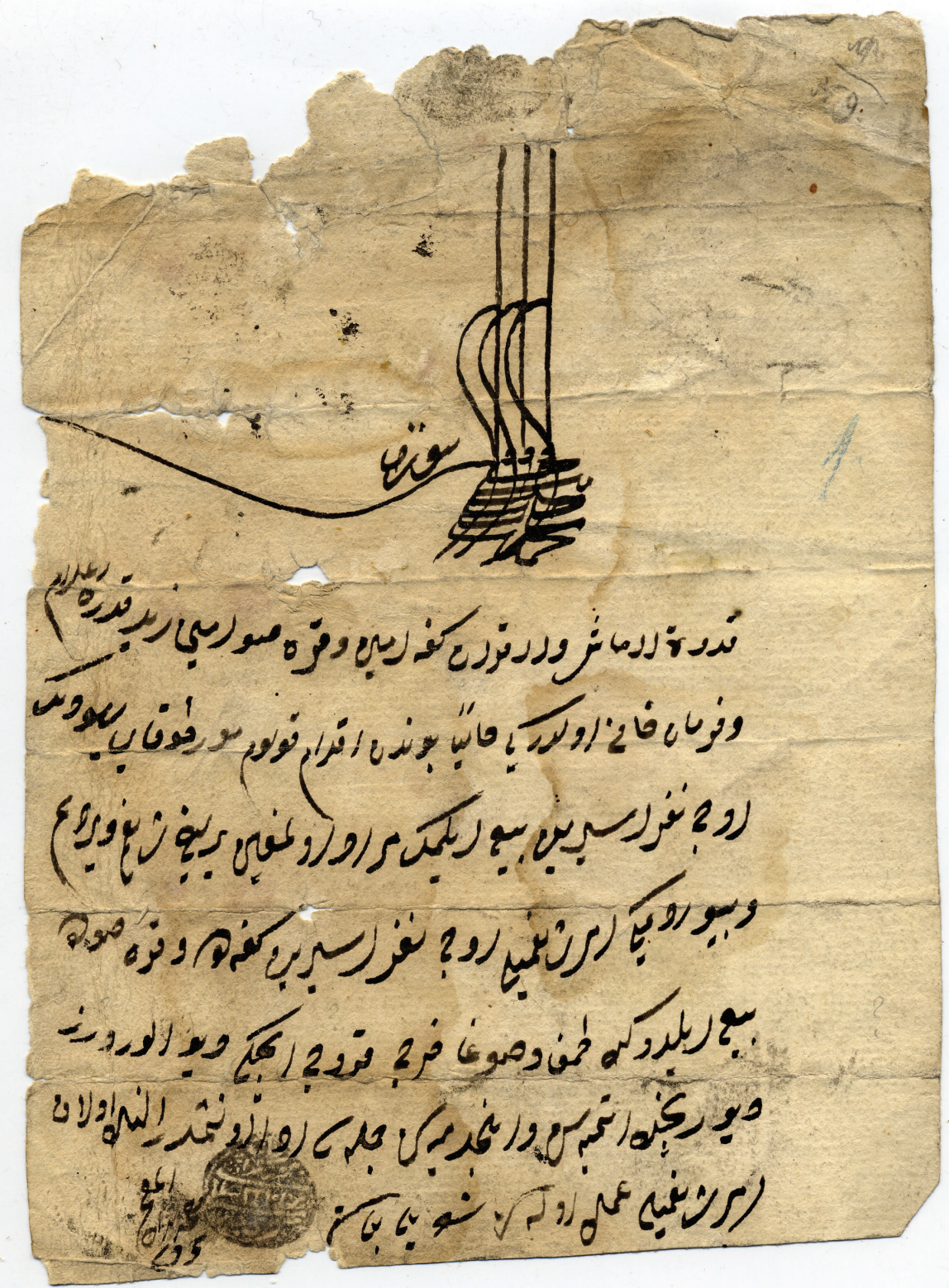

Yarlik of Muhammad Giray (1654-1656), giving the right to Mordehay to sell three slaves. National Library of Russia. Firk. I. Turk. doc., N. 9. 